\title{
Sm-Nd Age of the Fazenda Brasileiro Gabbro, Bahia, Brazil: Example of Robust Behavior of the Sm-Nd Isotopic System Under Extreme Hydrothermal Alteration
}

\author{
MÁRCIO M. PIMENTEL ${ }^{1}$ and MARIA DA GLÓRIA SILVA ${ }^{2}$ \\ ${ }^{1}$ Instituto de Geociências, Universidade de Brasília, 70910-900 Brasília, DF, Brasil \\ ${ }^{2}$ Departamento de Geologia de Geofísica Aplicada, Instituto de Geociências, UFBA \\ 40210-340 Salvador, BA, Brasil
}

Manuscript received on July 24, 2002; accepted for publication on April 9, 2003; contributed by MárCio M. PIMENTEL*

\begin{abstract}
The Fazenda Brasileiro gold mineralization is hosted by a gabbroic sill, intrusive into metavolcanicmetasedimentary rocks of the Rio Itapicuru Greenstone Belt, São Francisco Craton. The 2.05 Ga old mineralization is associated with intense shearing and hydrothermal alteration, and the host gabbro is altered to a series of rocks rich in sericite, chlorite, actinolite, carbonate and quartz.

Twelve whole-rock samples of the gold mineralization, representing varied degrees of alteration, from rocks with preserved igneous textures to the ore (quartz-carbonate-sulfide-chlorite), were studied by the $\mathrm{Sm}-\mathrm{Nd}$ method. All analytical points resulted in an isochron $(\mathrm{MSWD}=1.9)$ indicating the age of $2142+/-47 \mathrm{Ma}$ (1s) and Epsilon $\mathrm{Nd}(\mathrm{T})$ of +1.2 . Chlorite-sericite-carbonate rich hydrothermal rocks indicate the age of 2148 $+/-57 \mathrm{Ma}$ and Epsilon $\mathrm{Nd}(\mathrm{T})$ of +1.1 . The positive Epsilon $\mathrm{Nd}(\mathrm{T})$ suggest limited or no contamination with older continental crust, compatible with an oceanic setting for the tholeiites.

Combined with REE data, the Sm-Nd isotopic results reveal that the hydrothermal alteration, although intense, was unable to alter significantly the $\mathrm{Sm} / \mathrm{Nd}$ ratios of the original igneous rocks and did not cause important scatter of the analytical points, providing a rare example of robust behavior of the isotopic system, even under intense hydrothermal alteration.
\end{abstract}

Key words: Rio Itapicuru greenstone belt, Fazenda Brasileiro, Paleoproterozoic, gold mineralization, Sm$\mathrm{Nd}$, hydrothermal alteration.

\section{INTRODUCTION}

During the last two decades, the Sm-Nd isotopic systematics has been applied to investigate the most varied aspects of crustal evolution, such as the petrogenesis of granite batholiths, continental crust formation and growth, sediment provenance, origin of

\footnotetext{
*Member of Academia Brasileira de Ciências

Correspondence to: Márcio M. Pimentel

E-mail: marcio@unb.br/mmp1103@terra.com.br

E-mail: gloria@ufba.br
}

ore deposits, age of metamorphic events, among others (e.g. De Paolo and Wasserburg 1976, DePaolo 1981, Dickin and McNutt 1989, Murphy and Nance 2002, Pimentel et al. 2001, Stern 2002, Thorogood 1990).

The systematics is based on the alpha decay of ${ }^{147} \mathrm{Sm}$ to ${ }^{143} \mathrm{Nd}\left(\lambda{ }^{147} \mathrm{Sm}\right.$ of $6.54 \times 10^{-12}$ /year $)$. Both parent and daughter elements are light rareearth elements with similar ionic radii and valencies. 
Contrasting with other natural decay systems, the geochemical properties and behavior of the parentdaughter pair are very similar and the $\mathrm{Sm} / \mathrm{Nd}$ ratio is normally considered to be resistant to changes due to intracrustal processes. This enables the calculation of $\mathrm{T}_{\mathrm{DM}}$ model ages which are able to provide information on the age of regional crustal formation events, although it has been demonstrated that model ages not always equate to crust formation ages, and that they may only be used with caution. It is generally believed, however, that some processes such as the fractionation of LREE-bearing phases (monazite or allanite) or intense hydrothermal alteration can indeed modify substantially the $\mathrm{Sm} / \mathrm{Nd}$ ratio of a rock (e.g. Pimentel and Charnley 1990) and, therefore, interfere with $\mathrm{Sm}-\mathrm{Nd}$ model and isochron age calculations.

The Sm-Nd system has often been used to date mafic and ultramafic complexes. During crystallization of mafic magmas, $\mathrm{Nd}$ is slightly more incompatible than $\mathrm{Sm}$, becoming relatively more enriched in the residual liquids. Therefore, the most differentiated melts have lower $\mathrm{Sm} / \mathrm{Nd}$ ratios, enabling the construction of whole-rock Sm-Nd isochrons. For a group of whole-rock samples from the same magma source, which has not been substantially affected by subsequent alteration events, the isochron diagram yields the crystallization age of the complex. However due to the natural limited variation in $\mathrm{Sm} / \mathrm{Nd}$ ratios, the $\mathrm{Sm}-\mathrm{Nd}$ isochron age data are always less precise than those obtained with other methods such as U-Pb in zircon and badelleyite or the Ar-Ar method. The advantage is that the isochron also indicates the initial isotopic composition of the system, converted to $\varepsilon_{\mathrm{Nd}}$ value, which has significance to the petrogenesis of the original magma and to tectonic interpretations.

The calculation of reliable Sm-Nd whole-rock isochron ages for igneous rocks depend on the assumption that $\mathrm{Sm} / \mathrm{Nd}$ ratios of the samples used have not been substantially modified by metamorphism, hydrothermal alteration or weathering. Different degrees of alteration in the rock samples investigated may variably alter their $\mathrm{Sm} / \mathrm{Nd}$ ratios, and, in such cases, significant scatter in the isochron diagram should be expected, preventing construction of the isochron. In this study we report $\mathrm{Sm}-\mathrm{Nd}$ isotopic data for whole-rock samples of extremely and variably hydrothermally altered and metamorphosed mafic complex, transformed mostly into micaschists, which hosts the Paleoproterozoic Fazenda Brasileiro gold mineralization, Itapicuru greenstone belt, Bahia. Samples representing varied degrees of hydrothermal alteration were analyzed and the resulting data represents an example of robust behavior of the Sm-Nd system even after extreme hydrothermal alteration.

\section{GEOLOGICAL SETTING}

\section{The Rio Itapicuru Paleoproterozoic}

\section{Greenstone Belt}

The Rio Itapicuru greenstone belt is located in the northeastern part of the São Francisco Craton (Figure 1)

The Itapicuru volcano-sedimentary sequence and associated granite-gneiss terrains underlie an area of ca. $8400 \mathrm{~km}^{2}$ consisting mostly of strips of supracrustal rocks extending in the NNW direction. Only in the southern part of the belt the foliation has an EW regional trend. These supracrustals are associated with tonalitic-granodioritic gneissic units forming the gneissic basement, and are intruded by large N-S elongated granitoid domes (Figure 2). A complete review of the Rio Itapicuru sequence and its gold mineralization was presented by Silva et al. (2001a, b).

The supracrustal sequence of the Rio Itapicuru greenstone belt was initially compared to Archean greenstone belt sequences during the pioneer geological studies carried out in the 70's (Mascarenhas 1973, Kishida and Riccio 1980) when the Rio Itapicuru Greenstone Belt was characterized. Later geochronological studies have revealed the Paleoproterozoic age of the Rio Itapicuru volcanic rocks and associated granitoid domes (Brito Neves et al. 1980, Silva 1992, 1996, Mello 2000).

The volcano-sedimentary pile can be divided 


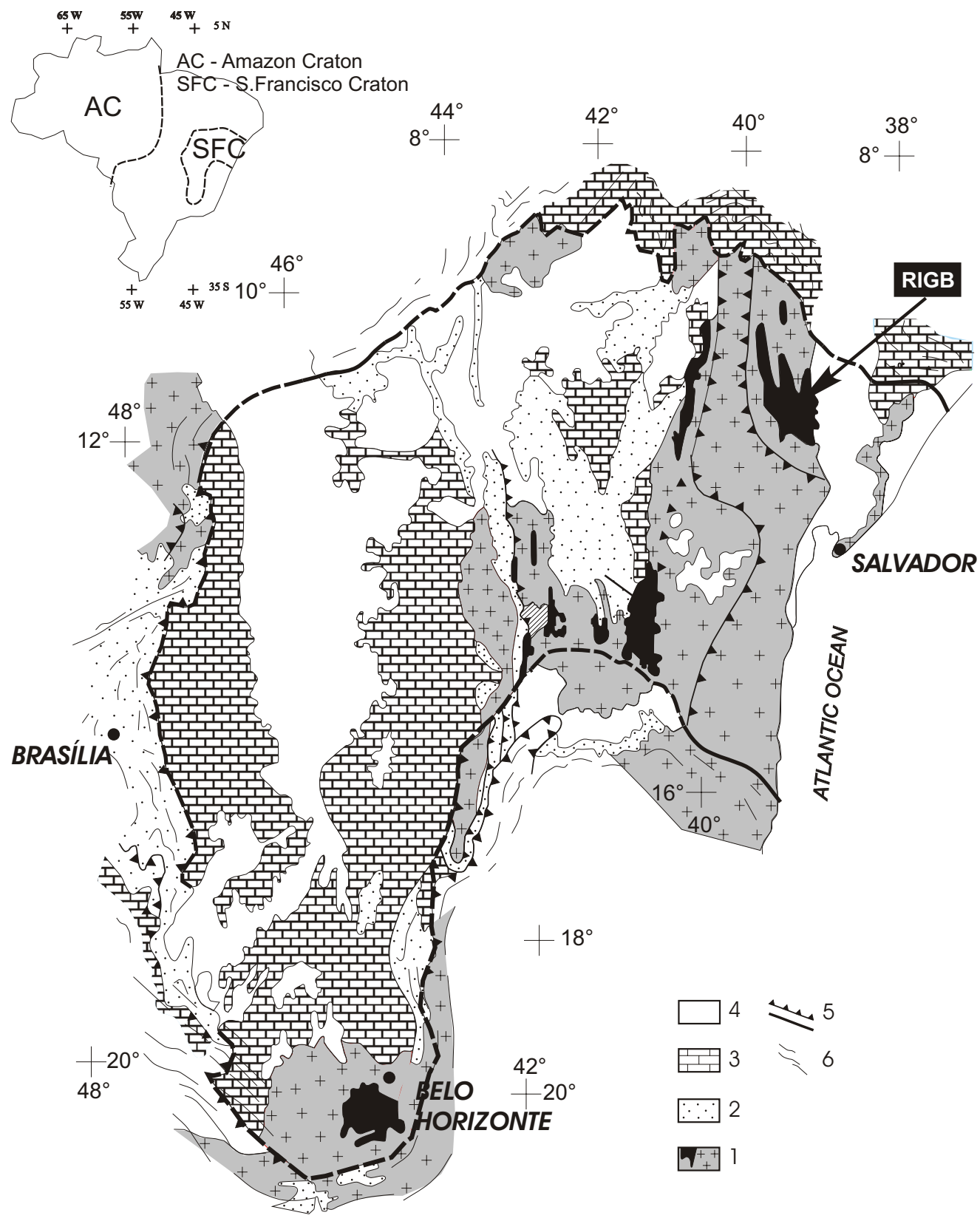

1: Archean and Paleoproterozoic terrains;

2: Meso/Neoproterozoic sedimentary cover;

3: Neoproterozoic sedimentary cover;

4: Tertiary/Quaternary cover;

5: Faults and thrusts;

6: Folded zones.

\section{GBRI - Rio Itapicuru Greenstone Belt}

Fig. 1 - Geological sketch map of the São Francisco Craton showing the location of the Rio Itapicuru Greenstone Belt (RIGB). 


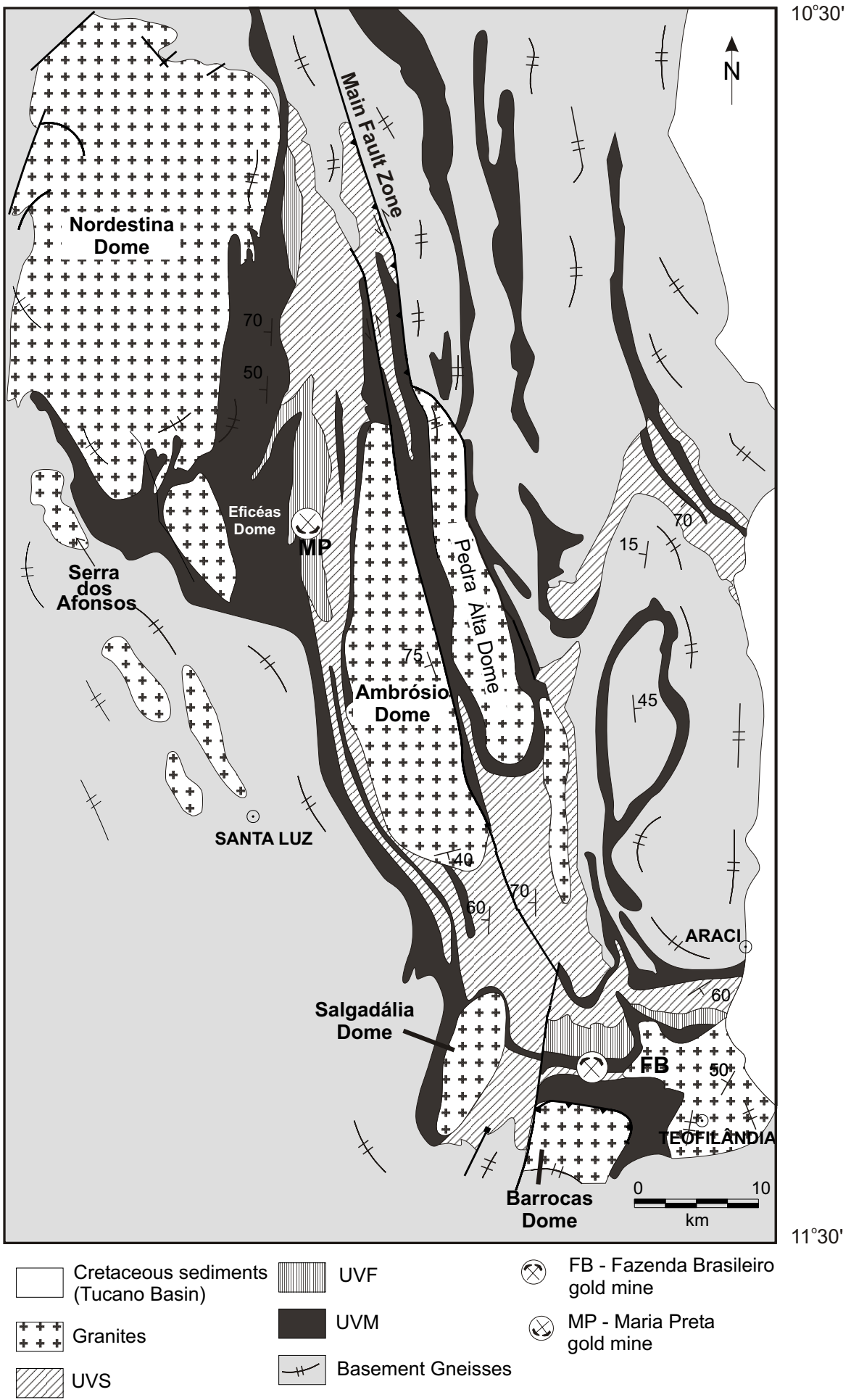

Fig. 2 - Geological map of the Rio Itapicuru Greenstone Belt showing the location of the Fazenda Brasileiro gold mine (after Silva et al. 2001b). UVS-Volcano-sedimentary unit, UVF - Felsic volcanic unit, UVM - Mafic volcanic unit. 
into the following units.

1. Basal mafic volcanic unit formed by metabasalts displaying abundant primary volcanic features such as pillows, flow breccias, and vesicular textures. Thin layers of pelitic (graphite schist) and chemical (metachert, iron and manganese formation) sediments are common; small mafic intrusions similar in composition to the volcanics are also found within the volcanic pile;

2. Felsic-intermediate volcanic unit formed by lavas and pyroclastic deposits of andesitic to dacitic composition, and also by small coeval subvolcanic intrusions;

3. Upper sedimentary unit comprising conglomerates, sandstones, siltstones, and shales.

The basal mafic volcanics and associated small gabbroic intrusions are equivalent to $\mathrm{Fe}$-rich tholeiites, and have general chemical characteristics of enriched MORB's, while felsic to intermediate metavolcanics are calc-alkaline (Silva 1987). Wholerock $\mathrm{Rb}-\mathrm{Sr}$ and $\mathrm{Pb}-\mathrm{Pb}$ isochrons for meta-andesites and metabasalts indicated ages of ca. 2.09 and 2.21 Ga, respectively (Brito Neves et al. 1980, Silva 1992, 1996). Sm-Nd $\mathrm{T}_{\mathrm{DM}}$ model ages between 2.1 and $2.2 \mathrm{Ga}$ for the mafic and intermediate rocks, positive values for $\varepsilon_{\mathrm{Nd}}$, as well as the low initial ${ }^{87} \mathrm{Sr} /{ }^{86} \mathrm{Sr}$ ratio for meta-andesites, indicate the primitive, oceanic, character of the igneous protoliths (Silva 1996).

The supracrustal and regional gneissic terrains were intruded by a number of granitoid bodies forming dome-like structures, elongated in the N-S direction (Figure 2). The intrusions vary in composition from calk-alkaline rocks to alkali-rich and shoshonitic granitoids. SHRIMP and conventional $\mathrm{U}-\mathrm{Pb}$ ages for the domes are within the interval between ca. 2.15 and 2.08 Ga (Batista et al. 1998, Alves da Silva 1994, Chauvet et al. 1997, Mello 2000). Archean inheritance is observed in some of the northern intrusions, such as the Ambrósio dome (Mello 2000).
Metamorphic mineral assemblages in the supracrustal rocks indicate an early low-grade, ocean floor alteration event originating spilites, followed by a regional metamorphic event at the greenschist facies conditions in the central part of the volcano-sedimentary belts and amphibolite facies conditions near the contacts with the granitoid domes. The regional metamorphic event was dated by the Ar-Ar method on hornblende at ca. $2.08 \mathrm{Ga}$ (Mello 2000).

\section{THE FAZENDA BRASILEIRO Au MINERALIZATION}

The Fazenda Brasileiro gold mineralization is located in an EW section of the supracrustal sequence, in the southern part or the Rio Itapicuru greenstone belt and is mainly hosted by a differentiated gabbroic sill, emplaced along the contact of mafic and felsic metavolcanic rocks (Kishida et al. 1991). It is the most important deposit of the volcano-sedimentary sequence, having produced $c a .53 \mathrm{t}$ of gold since 1984. The mineralization is associated with an EW shear zone and intense quartz veining and hydrothermal alteration, which have transformed the host gabbro into a series of hydrothermal rocks such as: (i) quartz-chlorite-actinolite schist with variable amounts of magnetite, known as CLX, which represents the main direct host of the mineralization, (ii) sericite-chorite-actinolite-carbonate schist (CAX), and (iii) albite+carbonate+sulfide rock cut by quartz veins with gold, known as SUF, which represents the main ore zone. Hydrothermal muscovite was dated with the Ar-Ar method and revealed the ages of $2050 \pm 4 \mathrm{Ma}$ and $2054 \pm 2 \mathrm{Ma}$, representing the best estimate available for the age of hydrothermal alteration (Mello 2000).

The work by Silva et al. (2001b), based on trace element data, reveals very similar REE patterns for the metagabbros, CLX, CAX and SUF (see Figure 30 in Silva et al. 2001b). REE patterns are generally flat, with a small but noticeable enrichment in the LREE. However, different REE contents are observed for these lithologies, with the metagabbros showing the lowest $\Sigma$ REE. REE contents increase 
towards CAX and CLX and are the highest in the SUF rock. This has been interpreted as an original igneous feature, resulting from magmatic differentiation of the gabbroic sill. Negative Eu anomalies are common in the most hydrothermally altered rocks, and have been explained by the complete substitution of Ca-rich plagioclase by alteration products such as albite, carbonate and white mica (Silva et al. 2001b). This means that the hydrothermal alteration affecting the gabbroic sill was unable to significantly modify the REE patterns, a feature which is relevant to Sm-Nd geochronology.

\section{SAMPLES AND ANALYTICAL PROCEDURES}

All samples used in this study come from two drill cores in the Fazenda Brasileiro gold mine. They represent fresh, unweathered, examples of rocks which suffered varied degrees of hydrothermal alteration, ranging from metagabbros to micaschists (hydrothermalites). Samples MGB (metagabbro) show preserved igneous sub-ophitic textures, while samples CAX and CLX are direct products of transformation of the gabbro. Sample SUF represents the sulfide- and quartz vein-rich ore zone.

$\mathrm{Sm}-\mathrm{Nd}$ isotopic analyses followed the method described Gioia and Pimentel (2000) and were carried out at the Geochronology Laboratory of the University of Brasília. Whole rock powders (ca. $50 \mathrm{mg}$ ) were mixed with ${ }^{149} \mathrm{Sm}^{-150} \mathrm{Nd}$ spike solution and dissolved in Savillex capsules or in sealed Teflon bombs. Sm and Nd extraction of whole-rock samples followed conventional cation exchange techniques, using teflon columns containing LN-Spec resin (HDEHP - di-ethylhexil phosphoric acid supported on PTFE powder). Sm and Nd samples were loaded on Re evaporation filaments of double filament assemblies and the isotopic measurements were carried out on a multi-collector Finnigan MAT 262 mass spectrometer in static mode. Uncertainties for $\mathrm{Sm} / \mathrm{Nd}$ and ${ }^{143} \mathrm{Nd} /{ }^{144} \mathrm{Nd}$ ratios are better than $\pm 0.2 \%(2 \sigma)$ and $\pm 0.005 \%(2 \sigma)$ respectively, based on repeated analyses of international rock standards BHVO- 1 and BCR-1. ${ }^{143} \mathrm{Nd} /{ }^{144} \mathrm{Nd}$ ratios were normalized to ${ }^{146} \mathrm{Nd} /{ }^{144} \mathrm{Nd}$ of 0.7219 and the decay constant $(\sigma)$ used was $6.54 \times 10^{-12}$. Isochron age was calculated using Isoplot/Ex v.2.47 (Ludwig 2001).

\section{RESULTS}

$\mathrm{Sm}-\mathrm{Nd}$ isotopic results are listed in Table I. Twelve samples of the several petrographic types associated with the gold mineralization (MGB, CLX, CAX, SUF) were studied. Samples analyzed have ${ }^{147} \mathrm{Sm} /$ ${ }^{144} \mathrm{Nd}$ ratios varying between ca. 0.14 and 0.22 and their REE concentrations, roughly agrees with the observed by Silva et al. (2001a, b): metagabbro samples have low LREE contents ( $\mathrm{Sm}$ between 1.0 and $1.6 \mathrm{ppm}$ and $\mathrm{Nd}$ between 3.2 to $4.6 \mathrm{ppm}$ ), while CLX and SUF hydrothermal rocks have higher concentrations of LREE. Nd concentrations in the CLX are between 3.3 and $27.5 \mathrm{ppm}$ and is $23.7 \mathrm{ppm}$ in the SUF sample. This increase in REE concentrations is not accompanied, however, by a change in the $\mathrm{Sm} / \mathrm{Nd}$ ratio, with all petrographic types presenting wide variations in ${ }^{147} \mathrm{Sm} /{ }^{144} \mathrm{Nd}$ values.

A regression line with all twelve analytical points resulted in a reasonably well defined isochron (MSWD = 1.9) indicating the age of $2142 \pm 47 \mathrm{Ma}$ $(1 \sigma)$ and $\varepsilon_{\mathrm{Nd}}(\mathrm{T})$ of +1.2 . The age is similar to those $\mathrm{Pb}-\mathrm{Pb}$ and $\mathrm{Rb}-\mathrm{Sr}$ isochron ages available in the literature for these rocks (Silva 1996, Brito Neves et al. 1980). The positive $\varepsilon_{\mathrm{Nd}}(\mathrm{T})$ value is also compatible with the preliminary data from Silva (1996), which found $\varepsilon_{\mathrm{Nd}}(\mathrm{T})$ values between +2 and +4 for mafic metavolcanics of the Fazenda Brasileiro region. Regression calculated only with the hydrothermalites CLX and CAX yield an identical isochron age of $2148 \pm 57 \mathrm{Ma}(1 \sigma)$, with $\varepsilon_{\mathrm{Nd}}(\mathrm{T})$ of +1.2 , and three samples of fairly preserved metagabbro define a line with a slope indicating the age of ca. 2.18 and $\varepsilon_{\mathrm{Nd}}$ (T) of +1.1 . Therefore, despite intense hydrothermal alteration, important scatter of analytical points in the Sm-Nd isochron diagram is not observed, and the $\mathrm{Sm}-\mathrm{Nd}$ isotopic system indicates the age of the original igneous rock.

The positive value for the $\varepsilon_{\mathrm{Nd}}(\mathrm{T})$ suggests lit- 

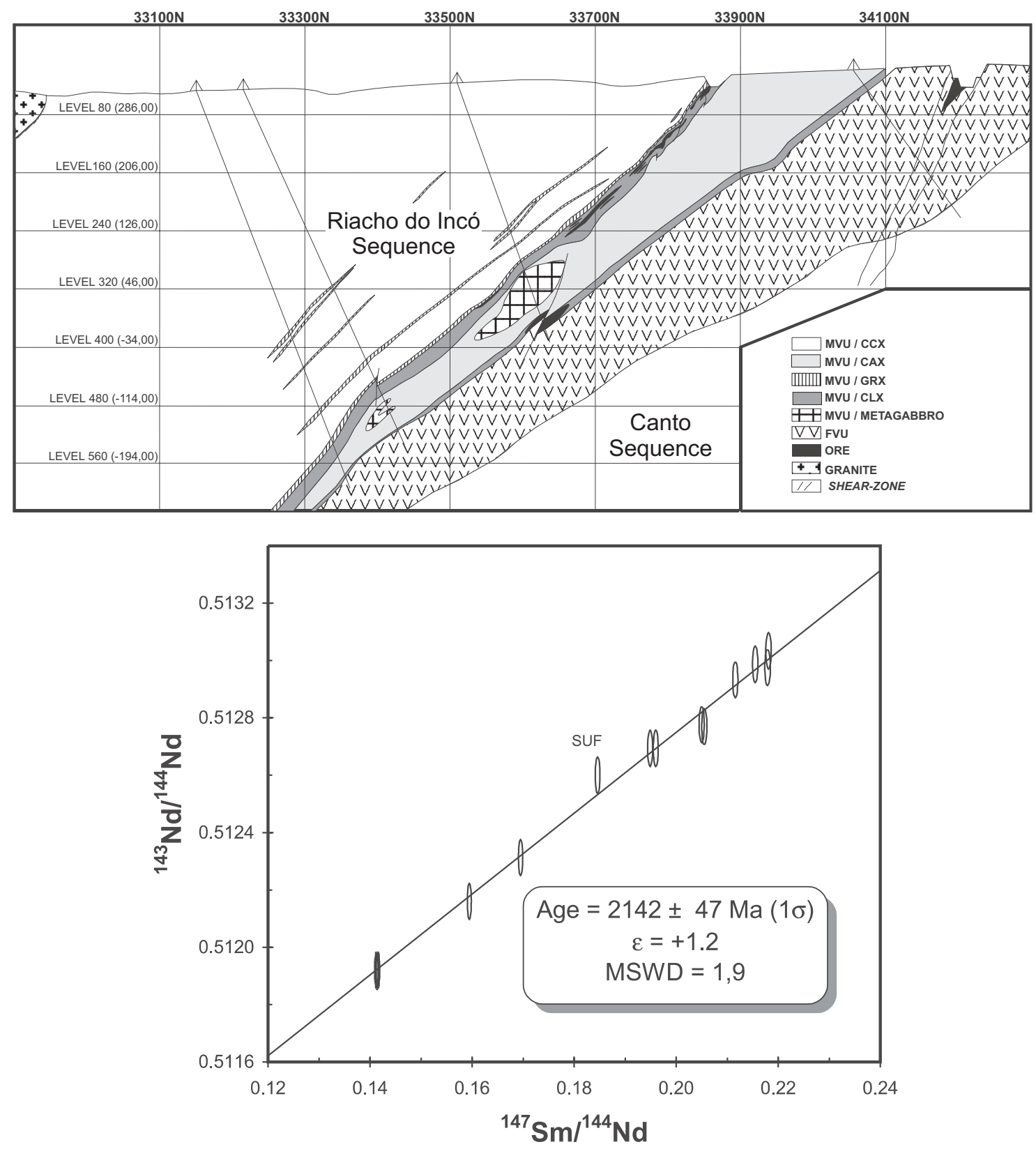

Fig. 3 - Cross section of the Fazenda Brasileiro mineralization and the Sm-Nd whole-rock isochron for the gabbro host-rock (after Silva et al. 2001b). MVU - mafic volcanic unit, CCX - carbonate chlorite schist, CAX - carbonate albite schist, GRX - garnet schist, CLX - chlorite schist, FVU - felsic volcanic unit.

tle or no contamination with older crustal material. The fact that the ore rich zone (SUF) also aligns, within uncertainties, along the same regression line, suggests that the ore metals and the mafic magmas are cogenetic.

\section{CONCLUSIONS}

The Sm-Nd isotopic results presented in this study, associated with previous REE studies on the same rocks samples (Silva et al. 2001b), allow the following conclusions: 
TABLE I

Sm-Nd isotopic data for the Fazenda Brasileiro gabbro and associated hydrothermal rocks.

\begin{tabular}{c|c|c|c|c|c}
\hline Sample & $\mathrm{Sm}(\mathrm{ppm})$ & $\mathrm{Nd}(\mathrm{ppm})$ & ${ }^{147} \mathrm{Sm} /{ }^{144} \mathrm{Nd}$ & ${ }^{143} \mathrm{Nd} /{ }^{144} \mathrm{Nd}$ & $\pm 2 \sigma$ error \\
\hline $935-18$ (CLX) & 1.220 & 3.381 & 0.218 & 0.513034 & 08 \\
$1468-08$ (CLX) & 3.195 & 9.862 & 0.196 & 0.512694 & 11 \\
$1468-19$ (CLX) & 1.853 & 5.499 & 0.205 & 0.512777 & 11 \\
$935-02$ (CLX) & 4.154 & 12.887 & 0.195 & 0.512694 & 08 \\
$1468-02$ (CLX) & 6.441 & 27.544 & 0.141 & 0.511920 & 09 \\
$935-10$ (cax) & 2.249 & 8.067 & 0.170 & 0.512313 & 09 \\
$1468-24$ (CAX) & 0.239 & 2.663 & 0.212 & 0.512933 & 09 \\
$1468-25$ (CAX) & 0.926 & 2.724 & 0.206 & 0.512769 & 06 \\
$935-22$ (MGB) & 1.155 & 3.204 & 0.218 & 0.512976 & 08 \\
$935-24$ (MGB) & 0.965 & 3.658 & 0.159 & 0.512160 & 08 \\
$935-26$ (MGB) & 1.647 & 4.647 & 0.216 & 0.512987 & 07 \\
$1468-11$ (suf) & 7.259 & 23.769 & 0.185 & 0.512555 & 07 \\
\hline
\end{tabular}

1. Samples of metagabbro and its hydrothermal alteration products, associated with the Fazenda Brasileiro gold mine, yielded a well defined Sm-Nd isochron indicating the age of ca. 2.14 $\mathrm{Ga}$ and $\varepsilon_{\mathrm{Nd}}(\mathrm{T})$ value of +1.2 . This agrees with previously published ages for the metavolcanic rocks associated with the gabbro sill, and is here interpreted as the crystallization age of the original mafic magma;

2. Positive value for $\varepsilon_{\mathrm{Nd}}(\mathrm{T})(+1.2)$ is compatible with little or no crustal contamination of the original magma, which is compatible with an oceanic setting for the sequence, in accordance with the model put forward by Silva (1987), in which the basal metabasalts in southern part of the Rio Itapicuru sequence have oceanic geochemical nature and were probably extruded in a back arc setting;

3. Concentrations of LREE seem to increase with increasing hydrothermal alteration. $\mathrm{Sm} / \mathrm{Nd}$ ratios however do not show any clear trend, suggesting that if the increase in REE concentrations results from the hydrothermal event, this was not capable of modifying substantially the $\mathrm{Sm} / \mathrm{Nd}$ ratio, allowing the calculation of a meaningful Sm-Nd isochron; an alternative interpretation for the increase in REE concentrations is that suggested by Silva et al. (2001b), which interprets this trend also as a primary igneous feature, indicative of the fractionation of the gabbroic sill;

4. Extreme hydrothermal alteration did not substantially affect the $\mathrm{Sm}-\mathrm{Nd}$ isotopic system. Hydrothermal rocks with chlorite, actinolite, sericite, carbonate and quartz, representing products of varied intensity of hydrothermal alteration of the original gabbro, still yielded a $\mathrm{Sm}-\mathrm{Nd}$ isochron with the age at ca. $2.14 \mathrm{Ga}$, when one should have expected considerable scatter in the isochron diagram. The ore rich zone (SUF) also plots on the regression line, suggesting that ore metals and original mafic magma are cogenetic;

5. The Sm-Nd isotopic composition of the Fazenda Brasileiro hydrothermal rocks represent a case in which the whole-rock $\mathrm{Sm}-\mathrm{Nd}$ isotopic 
system was not substantially disturbed, behaving in a robust manner, and preserving the original age of the mafic rock.

\section{ACKNOWLEDGMENTS}

The authors are grateful to PADCT for the financial support for field and laboratory work. Special gratitude is due to Dr. Onildo J. Marini-ADIMB for the support and encouragement.

\section{RESUMO}

A mineralização de ouro de Fazenda Brasileiro é hospedada por um sill gabróico intrusivo em rochas metavulcânicas/metassedimentares do Greenstone Belt do Rio Itapicuru, Craton do São Francisco. A mineralização, com idade de ca. $2.05 \mathrm{Ga}$, está associada com forte cizalhamento e alteração hidrotermal, e o gabro hospedeiro está alterado para rochas ricas em clorita, actinolita, carbonato e quartzo. Doze amostras de rocha total representando graus variados de alteração hidrotermal, desde rochas com texturas ígneas reliquiares até o minério (quartzo-carbonato-sulfeto-clorita), foram estudadas pelo método $\mathrm{Sm}-\mathrm{Nd}$. Os pontos analíticos formaram uma isócrona (MSWD $=1.9)$ indicando a idade de $2142 \pm 47 \mathrm{Ma}$ (1s) e Epsilon $\mathrm{Nd}(\mathrm{T}) \mathrm{de}+1.2$. Hidrotermalitos ricos em clorita, sericita, actinolita, carbonato e quartzo indicam uma idade de $2148 \pm 57 \mathrm{Ma}(1 \mathrm{~s})$ com Epsilon $\mathrm{Nd}(\mathrm{T})$ of +1.1. O Epsilon $\mathrm{Nd}(\mathrm{T})$ positivo sugere pouca ou nenhuma contaminação com crosta mais antiga, compatível com um ambiente oceânico para os toleitos.

Combinados com os dados de ETR, os dados isotópicos Sm-Nd revelam que a alteração hidrotermal, apesar de intensa, foi incapaz de modificar substancialmente as razões $\mathrm{Sm} / \mathrm{Nd}$ das rochas ígneas originais, não causou desalinhamento dos pontos, fornecendo um raro exemplo de comportamento robusto do sistema isotópico $\mathrm{Sm}-\mathrm{Nd}$ em condições extremas de alteração hidrotermal.

Palavras-chave: greenstone belt Rio Itapicuru, Fazenda Brasileiro, Paleoproterozóico, mineralização aurífera, Sm-Nd, alteração hidrotermal.

\section{REFERENCES}

Alves Da Silva FC. 1994. Étude structurale du "Greenstone Belt" paleoproterozoique du rio Itapicuru (Bahia, Brésil). Doctorate Thesis, Université d'Orléans, Orléans, France, 311p.

Batista JJ, Nebitt RW and Pires PFR. 1998. Presença do embasamento Arqueano no Greenstone belt do Rio Itapicuru (Bahia) - resultados geocronológicos por ICP-MS/LA. In: Congresso Brasileiro DE Geologia, 40., Belo Horizonte, Anais... B. Horizonte, SBG, p. 67.

Brito Neves BB, Cordani UG and Torquato JRF. 1980. Evolução geocronológica do Precambriano do Estado da Bahia. In: INDA HAV AND DuARTe FB (eds), Geologia e Recursos Minerais do Estado da Bahia: textos básicos. Salvador, SME/CPM, vol. 3, 123p.

Chauvet A, Guerrot C, Alves da Silva FC and FAURE M. 1997. Géochronologie ${ }^{207} \mathrm{~Pb} /{ }^{206} \mathrm{~Pb}$ et ${ }^{40} \mathrm{Ar} /{ }^{39} \mathrm{Ar}$ des granites paléoproterozoïques de la ceinture de roches vertes du Rio Itapicuru (Bahia, Brésil). CR Acad Sci Paris, Sér. II 324: 293-300.

DePaolo DJ. 1981. Neodymium isotopes in the Colorado Front Range and crust-mantle evolution in the Proterozoic. Nature 29: 193-196.

DePaolo DJ and Wasserburg GJ. 1976. Nd isotopic variations and petrogenetic models. Geophys Res Lett 3: 249-252.

Dickin A AND McNutT RH. 1989. Nd model age mapping of the southeast margin of the Archean foreland in the Grenville Province of Ontario. Geology 17: 299-302.

Gioia SMCL and Pimentel MM. 2000. The Sm-Nd isotopic method in the Geochronology Laboratory of the University of Brasília. An Acad Bras Cienc 72: 219-245.

Kishida A AND Riccio L. 1980. Chemoestratigraphy of lava sequences from the Rio Itapicuru greenstone belt, Bahia, Brazil. Precamb Res 11: 161-178.

Kishida A, Sena FO and Alves da Silva FC. 1991. Rio Itapicuru greenstone belt: Geology and gold mineralization. In: LAdeIRA EA (ed) Proceedings of Gold' 91: The Economics, Geology, Geochemistry and Genesis of Gold Deposits, Balkema, Rotterdam, p. 49-59. 
LuDwIG KR. 2001. Users manual for Isoplot/Ex v. 2.47. A geochronological toolkit for Microsoft Excel. Berkeley Geochronology Center Sp. Publ., 1a.

Mascarenhas JF. 1973. A geologia do centro-leste do Estado da Bahia. In: Congresso Brasileiro DE Geologia, 28., Salvador, Anais... Salvador, SBG, pp. 35-66.

Mello EF. 2000. Estudos isotópicos do greenstone belt do Rio Itapicuru, BA: evolução crustal e metalogenia do ouro. Doctorate Thesis, Universidade de Campinas, São Paulo, 200pp.

Murphy JB and Nance RD. 2002. Sm-Nd isotopic systematics as tectonic tracers: an example from West Avalonia in the Canadian Appalachians. Earth-Sci Rev 59: 77-100.

Pimentel MM and Charnley N. 1990. Instracrustal fractionation and implications for $\mathrm{Sm}-\mathrm{Nd}$ model age calculations in late-stage granitic rocks: an example from central Brazil. Chem Geol 86:123-138.

Pimentel MM, Dardenne MA, Fuck RA, Viana MG, Junges SL, SeER HJ AND Fischel DP. 2001. Nd isotopes and the provenance of sediments of the Neoproterozoic Brasília Belt, central Brazil. J South Am Earth Sci 14:571-585.

Silva MG. 1987. Geochemie, Petrologie und geotektonische Entwicklung eines proterozoischen Gruensteinguertel: Rio Itapicuru, Bahia, Brasilien. Doctorate Thesis, Univ. Freiburg, Germany.
SILVA MG. 1992. Evidências isotópicas e geocronológicas de um fenômeno de acrescimento crustal transamazônico no craton do São Francisco, Estado da Bahia. In: Congresso Brasileiro de GeoloGIA, 37., São Paulo, Anais, v.2... São Paulo, SBG, p. 181-182.

SiLva MG. 1996. Síntese e interpretação dos dados geocronológicos do terreno granito-greenstone do rio Itapicuru (BA). In: Congresso Brasileiro DE Geologia, 39, Salvador, Anais, v. 6... Salvador, SBG, p. 547-547.

Silva MG, Coelho CES, Teixeira JBG, Alves da Silva FC, Silva RA and Souza JAB. 2001a. The Rio Itapicuru greenstone belt, Bahia, Brazil: geologic evolution and review of gold mineralization. Miner Depos 36: 345-357.

Silva MG, Coelho CES, Teixeira JBG, Silva RA and OrLandi PH. 2001b. Mineralizações Auríferas do Greenstone Belt do Rio Itapicuru, Bahia, com ênfase no Depósito de Fazenda Brasileiro. In: Jost H, BROD JA AND Queiroz ET. (eds), Caracterização de Depósitos Auríferos em Distritos Mineiros Brasileiros, ed. Taguatinga: Bárbara Bela.

Stern R. 2002. Crustal evolution in the East African Orogen: a neodymium isotopic perspective. J African Earth Sci 34: 109-117.

Thorogood EJ. 1990. Provenance of the pre-Devonian sediments of England and Wales: Sm-Nd evidende. J Geol Soc. London 147: 591-594. 